\title{
B-286071
}

September 20, 2000

The Honorable Ernest J Istook, J r.

Chairman, Subcommittee on the District of Columbia

Committee on Appropriations

House of Representatives

\section{Subject: District of Columbia: Adolescent AIDS Prevention Program}

Dear Mr. Chairman:

In response to your request, we have reviewed the District of Columbia's Adolescent AIDS Prevention Program, which makes condoms available to students in the D.C. Public Schools. Specifically, you asked us to obtain (1) statistics on the specific schools that are participating in this program; (2) information about how the schools were selected to participate in the program; (3) the source and amount of funding identified in the D.C. government budget; (4) statistics on sexually transmitted diseases, human immunodeficiency virus/acquired immunodeficiency syndrome (HIV/AIDS), and pregnancies among D.C. public school students; ${ }^{1}(5)$ the policies that govern the distribution of all forms of contraception devices to students in the D.C. Public Schools; and (6) information on policies governing sex education in the D.C. Public Schools.

In summary, the Adolescent AIDS Prevention Program is administered by school nurses in all 17 of the District's currently operating public senior high schools, at the discretion of the Mayor, the D.C. Public Schools Superintendent, and the D.C. Health and Hospitals Public Benefit Corporation. Although the program is not a separate item in the D.C. budget, a D.C. Department of Health (DOH) official reported that the condoms distributed by school nurses in the 1999-2000 school year cost $\$ 2,625$ and were purchased through a grant from the Centers for Disease Control and Prevention (CDC). Information on the incidence of sexually transmitted diseases and HIV/AIDS among D.C. public high school students is not available. How ever, there were 1,862 reported cases of sexually transmitted diseases (about 55 per 1,000 teenagers) and fewer than 5 newly reported AIDS cases among all D.C. teenagers in 1999. For the 1998-99 school year, school nurses were aware of and monitoring 249 student

\footnotetext{
${ }^{1}$ HIV/AIDS can be contracted through means other than sexual contact and is counted separately from other sexually transmitted diseases. In addition to sexual transmission, HIV may be contracted in a number of ways, including contaminated needles, mother-to-child transmission through birth or breastfeeding, or transfusions of infected blood.
} 


\section{B-286071}

pregnancies among all D.C. public school students. The D.C. Health and Hospitals Public Benefit Corporation sets the policies governing the program, which allows condoms to be distributed only through school nurses and only after a student has specifically requested them. No other forms of contraception may be distributed in the D.C. Public Schools. The D.C. City Council established regulations that require the D.C. Public Schools to teach age-appropriate sex education as part of the regular curriculum; submit a list of all textbooks to be used for sex education to the D.C. Board of Education annually for approval; notify parents or guardians in writing before sex education is taught; and make all instructional materials available for inspection by parents or guardians of students receiving sex education.

To address your request, we collected data and policy documents from DOH, the D.C. Health and Hospitals Public Benefit Corporation, the D.C. State Center for Health Statistics, and the D.C. Public Schools. We also interviewed officials from each of these agencies, and reviewed the D.C. budget for fiscal year 2000 and the proposed budget for 2001. Although some data are available by school, we are presenting aggregated data to protect the confidentiality of students. We did not independently verify health statistics or statistics on the number of condoms distributed to public school students. In every other respect, our work was performed in accordance with generally accepted government auditing standards.

\section{BACKGROUND}

The Adolescent AIDS Prevention Program was implemented in all of D.C.'s public senior high schools and in four junior high schools in September 1992 under former Mayor Sharon Pratt Kelly. ${ }^{2}$ The program was part of Mayor Kelly's response to the rising incidence of HIV infection in the District. The program's objective is to prevent the spread of HIV infection among high school students in the D.C. Public Schools through a combination of (1) prevention education, (2) individual counseling, and (3) condom access.

As detailed in figure 1, the first component- prevention education-is taught to all high school students and is administered by the school nurse in cooperation with other relevant agencies and outside resources. The second component-individual counseling-is given only at the request of a student. School nurses and student peer educators ${ }^{3}$ are available to assist students who have concerns or questions about HIV/AIDS that they would like addressed privately.

\footnotetext{
${ }^{2}$ In the 1992-93 school year, there were 22 senior high schools in the District of Columbia. Since then, several of these high schools have closed, leaving a total of 17 public high schools, all of which continue to participate in the Adolescent AIDS Prevention Program. One of the participating junior high schools dropped out of the program in the 1993-94 school year and the remaining three dropped out in the 1996-97 school year.

${ }^{3}$ Student peer educators, also known as Peer AIDS Prevention Educators, are students who are trained to help their peers identify pressures that may lead to sexual involvement, to provide skill building workshops that encourage abstinence and safer sex, to network with other schools to promote AIDS prevention education activities, and to conduct AIDS prevention education activities within their schools.
} 


\section{Figure 1: Adolescent AIDS Prevention Program Components}

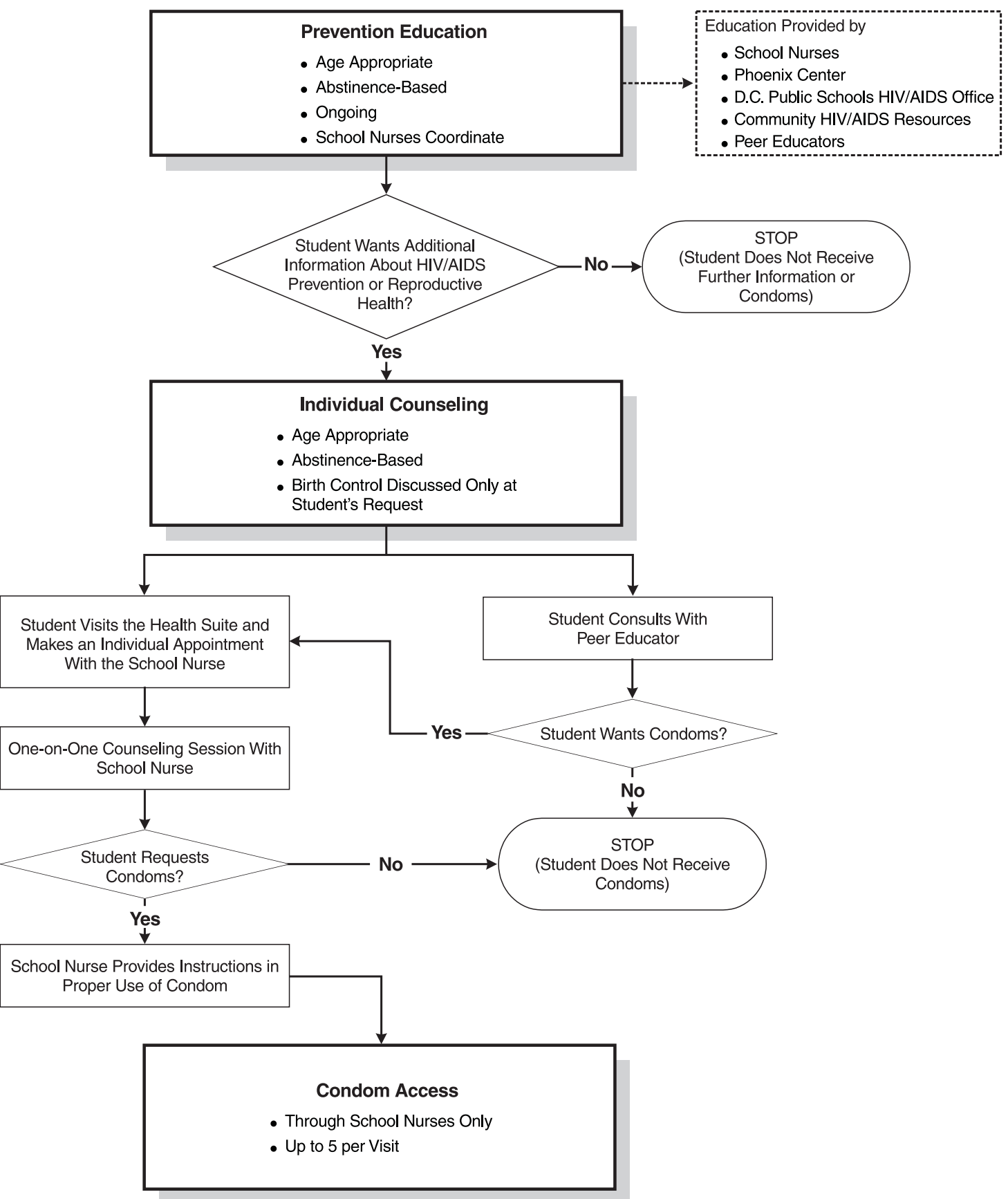




\section{B-286071}

Students do not automatically receive condoms through the Adolescent AIDS Prevention Program. Students must request condoms from a school nurse, who provides information about abstinence as an alternative to engaging in sexual activity in addition to providing instruction in how to use condoms to reduce the risk of HIV infection.

\section{STATISTICS AND POLICIES}

The Adolescent AIDS Prevention Program is administered in all 17 of the District's currently operating public senior high schools at the discretion of the Mayor, the D.C. Public Schools Superintendent, and the D.C. Health and Hospitals Public Benefit Corporation. Table 1 provides basic information about each of the participating schools, and figure 2 shows where these schools are located.

\section{Table 1: D.C. Public High Schools Participating in the Adolescent AIDS Prevention} Program

\begin{tabular}{|c|c|c|c|c|c|c|c|c|c|}
\hline Senior high school & Ward & $\begin{array}{c}\text { Number } \\
\text { of } \\
\text { students }^{\mathrm{a}}\end{array}$ & $\begin{array}{c}\text { Black } \\
(\%)^{a}\end{array}$ & $\begin{array}{c}\text { White } \\
(\%)^{a}\end{array}$ & $\begin{array}{c}\text { Hispanic } \\
(\%)^{\mathrm{a}}\end{array}$ & $\begin{array}{c}\text { Asian/ } \\
\text { Pacific } \\
\text { Islander } \\
(\%)^{\mathrm{a}}\end{array}$ & $\begin{array}{c}\text { Eligible } \\
\text { for free/ } \\
\text { reduced price } \\
\text { lunch } \\
(\%)^{b}\end{array}$ & $\begin{array}{c}\text { Promotion } \\
\text { rate } \\
(\%)^{\mathrm{a}}\end{array}$ & $\begin{array}{c}\text { Attendance } \\
\text { rate } \\
(\%)^{c}\end{array}$ \\
\hline Anacostia & 6 & 778 & 99.9 & 0.1 & 0.0 & 0.0 & 98.0 & 70.0 & 85.2 \\
\hline Ballou & 8 & 1,033 & 99.5 & 0.5 & 0.0 & 0.0 & 68.0 & 77.5 & 80.9 \\
\hline Banneker & 1 & 432 & 92.8 & 0.7 & 3.2 & 3.2 & 27.0 & 98.1 & 96.4 \\
\hline Bell Multicultural & 1 & 662 & 23.7 & 0.5 & 64.4 & 11.5 & 96.0 & 91.2 & Unavailable \\
\hline Cardozo & 1 & 825 & 75.5 & 0.4 & 20.7 & 3.3 & 79.0 & 80.1 & 90.1 \\
\hline Coolidge & 4 & 1,064 & 96.5 & 0.2 & 2.8 & 0.5 & 22.0 & 94.9 & 85.3 \\
\hline Dunbar & 5 & 697 & 99.0 & 0.0 & 0.9 & 0.1 & 77.0 & 86.9 & 84.2 \\
\hline Eastern & 6 & 1,543 & 99.5 & 0.1 & 0.4 & 0.1 & 77.0 & 85.4 & 88.6 \\
\hline \begin{tabular}{|l|} 
Ellington \\
School of the Arts \\
\end{tabular} & 2 & 489 & 86.9 & 8.8 & 3.9 & 0.4 & 36.0 & 87.7 & 87.4 \\
\hline Luke C. Moore Academy & 5 & 196 & 96.4 & 0.0 & 3.6 & 0.0 & 34.0 & 53.2 & 45.0 \\
\hline $\begin{array}{l}\text { Phelps Career Senior High } \\
\text { School }\end{array}$ & 5 & 435 & 99.8 & 0.2 & 0.0 & 0.0 & 88.0 & 74.2 & 94.3 \\
\hline Roosevelt & 4 & 703 & 78.9 & 0.0 & 20.1 & 0.7 & 49.0 & 86.7 & 81.8 \\
\hline School Without Walls & 2 & 339 & 64.9 & 19.5 & 8.0 & 7.4 & 11.0 & 95.4 & Unavailable \\
\hline \begin{tabular}{|l|} 
Joel Elias Spingarn \\
\end{tabular} & 5 & 580 & 99.0 & 0.2 & 0.7 & 0.2 & 62.0 & 79.0 & 78.7 \\
\hline $\begin{array}{l}\text { M. M. Washington Career } \\
\text { Senior High School }\end{array}$ & 5 & 383 & 97.4 & 0.0 & 2.3 & 0.3 & 42.0 & 94.1 & 86.4 \\
\hline Woodrow Wilson & 3 & 1,510 & 56.3 & 18.1 & 17.2 & 8.4 & 31.0 & 89.0 & 94.4 \\
\hline H. D. Woodson & 7 & 778 & 99.6 & 0.0 & 0.4 & 0.0 & 87.0 & 70.1 & 79.8 \\
\hline All senior high schools & & 12,447 & 85.4 & 3.2 & 9.0 & 2.3 & $57.9^{d}$ & $83.1^{d}$ & $83.9^{d}$ \\
\hline
\end{tabular}

${ }^{a}$ As of October 7, 1999.

${ }^{b}$ For school year 1999-2000.

${ }^{C}$ For school year 1998-99.

${ }^{d}$ Column average.

Source: D.C. Public Schools. 


\section{B-286071}

Figure 2: Locations of D.C. Public High Schools, by Ward

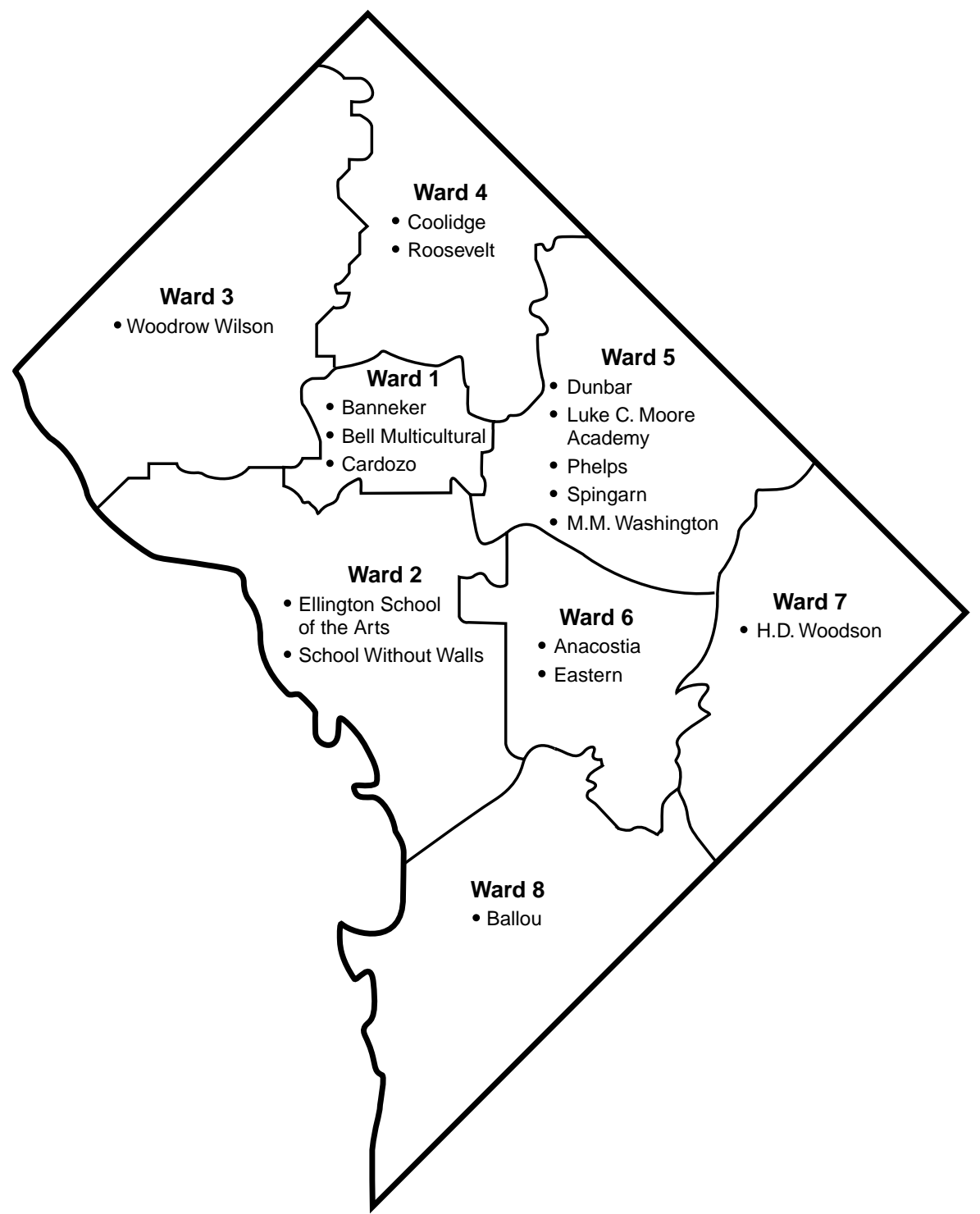

Sources: Map obtained from the D.C. Board of Elections and Ethics. School information obtained from the D.C. Public Schools.

The Adolescent AIDS Prevention Program is funded through the D.C. Health and Hospitals Public Benefit Corporation, which pays the salaries of the public school nurses who administer the program, and through $\mathrm{DOH}$, which purchases the condoms that nurses distribute to students. In fiscal year 1999, the Public Benefit Corporation's budget for school nursing services was $\$ 4,797,000$, but this total includes the services of school nurses who did not administer the Adolescent AIDS Prevention Program, and it covers all the services that school nurses perform. In the 1999-2000 school year, nurses at 17 high schools distributed 23,483 condoms to high school students, at a cost of about 10 cents per condom. DOH purchases the condoms that are made available to students with grant moneys received from CDC. The total cost of the condoms purchased by DOH for the 1999-2000 school year was $\$ 2,625$. 
Available statistics show that the number of condoms distributed to D.C. public high school students through the Adolescent AIDS Prevention Program has fluctuated since the program began, although there has been an overall increase in the number of condoms distributed. (See figs. 3 and 4.) The drop in the number of condoms distributed between the 1993-94 and 1994-95 school years is due, in part, to the phasing out of the program in junior high schools and the closure of a senior high school. Also, according to one Public Benefit Corporation official, a number of school nurses retired during this time period and were replaced with contract nurses, who were not permitted to distribute condoms. This official also attributed the sudden decline to waning interest in the program after its initial start-up.

Figure 3: Total Condoms Distributed in D.C. Public Schools, School Years 1992-93 Through 1999-2000

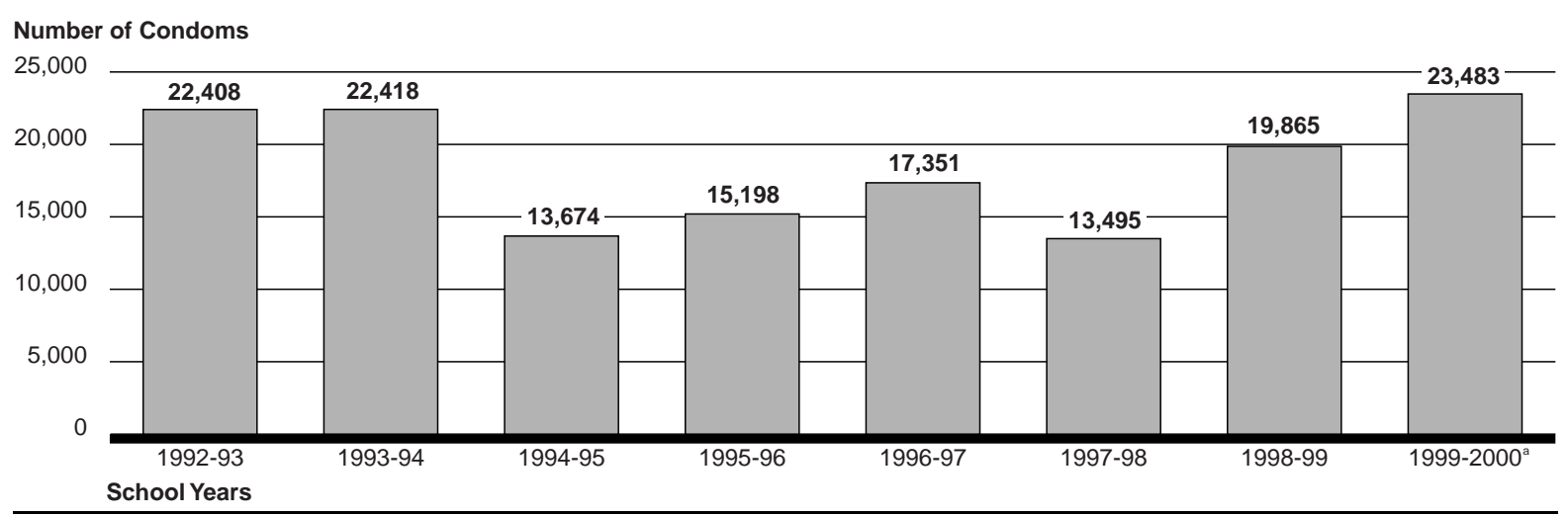

${ }^{a}$ Through May 2000.

Source: D.C. Health and Hospitals Public Benefit Corporation, Community and School Health Program. 
Figure 4: Average Number of Condoms Distributed per Student, School Years 1992-93 Through 1999-2000

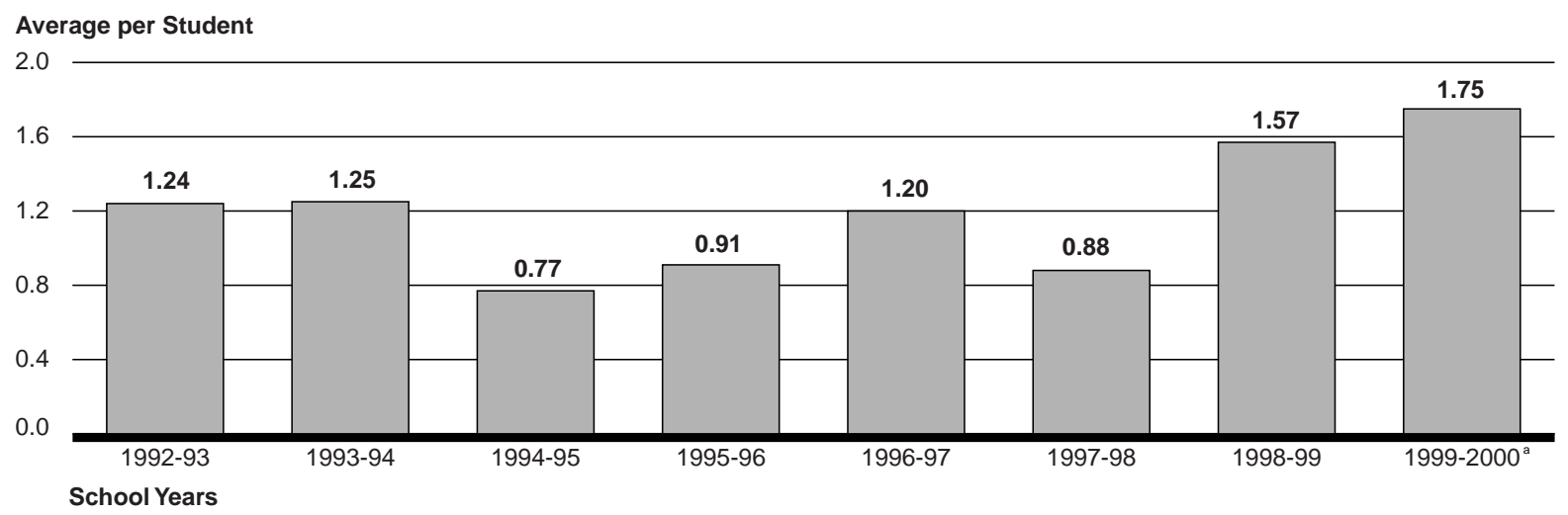

'Through May 2000.

Source: D.C. Health and Hospitals Public Benefit Corporation, Community and School Health Program.

According to $\mathrm{DOH}$, the total number of reported cases of sexually transmitted diseases among D.C. teenagers rose between 1996 and 1998. Much of the overall increase appears to be attributable to an increase in diagnosed cases of chlamydia. Cases of gonorrhea have declined since 1995, and syphilis cases have declined since 1996. However, it is not known how many public high school students in D.C. have been infected, because the D.C. Public Schools do not monitor the incidence of sexually transmitted diseases among students. The numbers reported by $\mathrm{DOH}$ include diagnosed cases of sexually transmitted diseases among all D.C. teenagers, including those who do not attend D.C. Public Schools and who do not participate in the Adolescent AIDS Prevention Program. The total number of cases decreased from 1998 to 1999. (See fig. 5.) 
Figure 5: Reported Cases of Sexually Transmitted Diseases Among D.C. Teenagers Aged 13 Through 19, 1995-2000

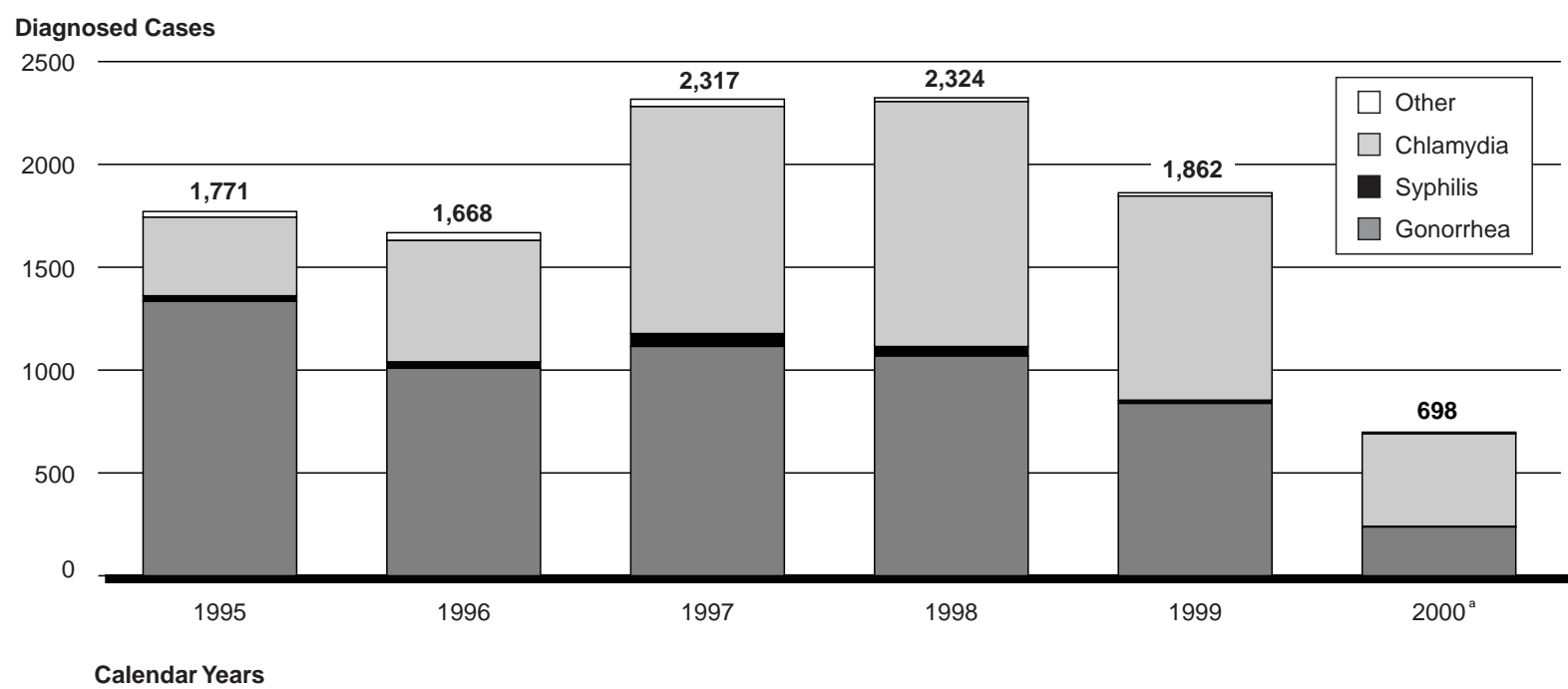

Note: Data for 1992 through 1994 are not consistent with those for 1995 through 2000 because of DOH reporting changes and are therefore excluded.

'Through J une 2000.

Source: DOH Bureau of Sexually Transmitted Disease Control.

The incidence of HIV infection among high school students in the D.C. Public Schools is not available for analysis because, in order to protect students' right to privacy, the D.C. Public Schools do not gather this information from students. DOH, however, reported that there were fewer than 5 new cases of AIDS reported for D.C. teenagers aged 13 through 19 in 1999 and that there have been fewer than 10 newly reported cases for D.C. teenagers in any given year since 1992.

The number of pregnancies among D.C. public school students has declined since the 1992-93 school year, which is in keeping with the national trend. ${ }^{4}$ However, these data account for all student pregnancies, not solely those identified among high school students. Also, these data may not reflect the total number of student pregnancies because they include only those pregnancies identified and monitored by the school nurses. (See fig. 6.)

\footnotetext{
${ }^{4} \mathrm{Nationally}$, the birth rate for adolescents dropped by more than one-fifth between 1991 and 1998. See Federal Interagency Forum on Child and F amily Statistics, America's Children: Key National Indicators of Well-Being, 2000 (Washington, D.C.: U.S. Government Printing Office, July 2000).
} 
Figure 6: Newly Reported Student Pregnancies Tracked by D.C. School Nurses, School Years 1992-93 Through 1999-2000

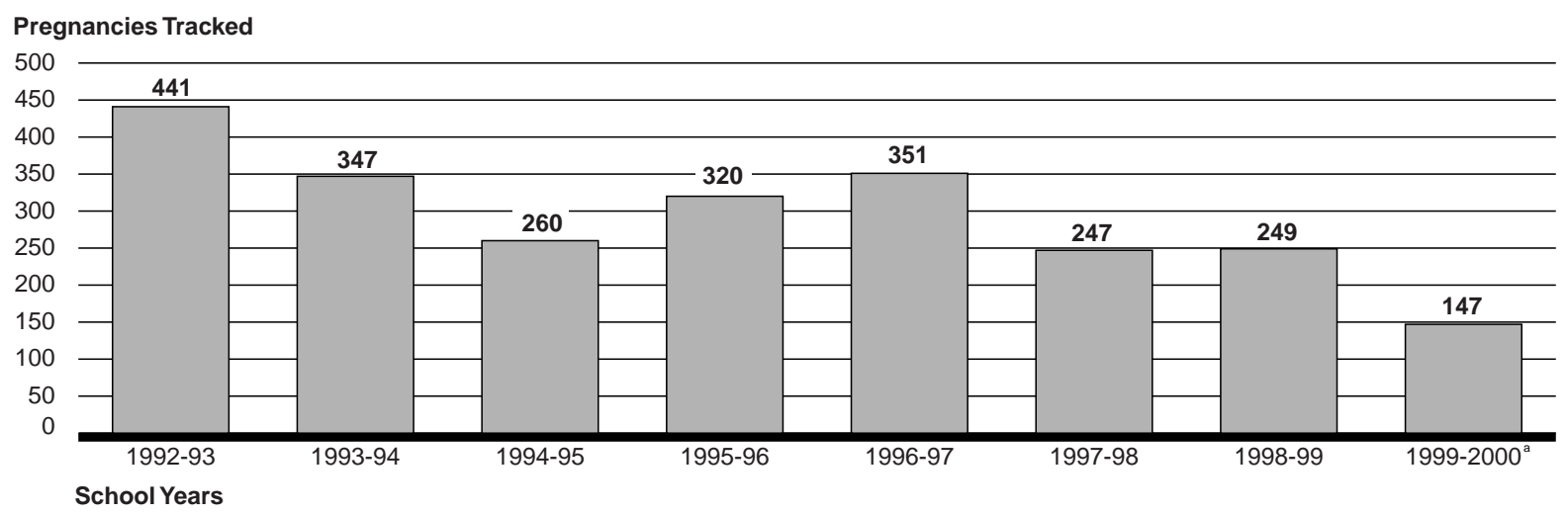

ªhrough May 2000.

Source: D.C. Health and Hospitals Public Benefit Corporation, Community and School Health Program.

The Adolescent AIDS Prevention Program, which is administered solely in public high schools, supplements the D.C. Public Schools sex education curriculum, which operates under regulations established by the D.C. City Council. ${ }^{5}$ The D.C. Public Schools Superintendent oversees the implementation of these regulations and establishes additional guidelines for schools. ${ }^{6}$ Currently, sex education is introduced in the $5^{\text {th }}$ grade and is part of the overall health and physical education curriculum. This curriculum includes 11 content areas ranging from human sexuality to nutrition and first aid. Students receive age-appropriate instruction on human sexuality and reproduction, including information on human anatomy, pregnancy and childbirth, sexually transmitted diseases, contraception, abortion, homosexuality, awareness and prevention of rape and other sex offenses, and discussion of the process of making personal decisions in matters involving sexuality. At the high school level, students are required to complete three semesters of health and physical education before they graduate, of which about one semester may be spent on sex education.

\footnotetext{
${ }^{5}$ Regulations that govern the teaching of human sexuality and reproduction in the D.C. Public Schools are included in the D.C. Municipal Regulations at D.C. Mun. Regs. tit. 5, 2305.

${ }^{6}$ The D.C. Public Schools Office of Academic Services currently is revising sex education guidelines for the D.C. Public Schools.
} 


\section{AGENCY COMMENTS}

Officials from the Health and Hospitals Public Benefit Corporation reviewed this correspondence and had no comments.

We are sending copies of this letter to Dr. Robin Newton, Interim Chief Executive Officer of the D.C. Health and Hospitals Public Benefit Corporation; Dr. Paul Vance, D.C. Public Schools' Superintendent; and Dr. Ivan Walks, Director, D.C. Department of Health. We will also provide copies to others on request.

Major contributors to this letter were David D. Bellis, Regina Santucci, and Sharon Price. Please contact me at (202) 512-7215 if you or your staff have any questions.

Sincerely yours,

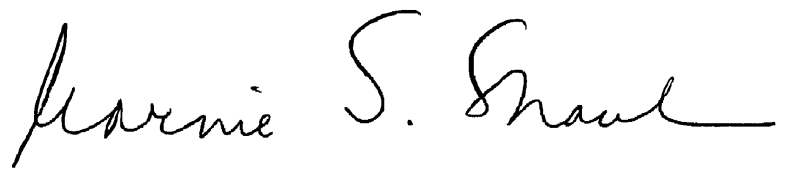

Marnie S. Shaul

Associate Director, Education, Workforce, and Income Security Issues 